\title{
MODELLING THE FARM SCALE IMPACTS OF CLOVER ROOT WEEVIL HERBIVORY
}

\author{
T.A. WHITE ${ }^{1}$ and P.J. GERARD ${ }^{2}$ \\ ${ }^{I}$ AgResearch, PO Box 60, Lincoln, New Zealand \\ ${ }^{2}$ AgResearch, Private Bag 3123, Hamilton, New Zealand \\ Corresponding author: todd.white@agresearch.co.nz.
}

\begin{abstract}
Clover root weevil (Sitona lepidus, CRW) is a major New Zealand pasture pest. This study used computer simulation and decision support modelling to simulate CRW herbivory, estimate the long-term consequences on clover abundance, pasture production and quality, and financial implications to a typical sheep and beef farmer. Three farm scenarios were explored, the absence of CRW and the presence of CRW with and without additional nitrogen $(\mathrm{N})$. For a hypothetical 325 ha Waikato sheep and beef farm, CRW decreased mean clover abundance from 21 to $13 \%$, pasture production from 9200 to $7900 \mathrm{~kg} \mathrm{DM} / \mathrm{ha} /$ year, pasture quality from 10.5 to $10.2 \mathrm{MJME} / \mathrm{kg} \mathrm{DM}$ and $\mathrm{N}$ fixation from 60 to $42 \mathrm{~kg} \mathrm{~N} / \mathrm{ha} /$ year. This resulted in a $16 \%$ reduction in the annual gross margin. However, assuming current prices and costs, and that an $\mathrm{N}$ response could be consistently achieved, urea could be used to replace the reduction in $\mathrm{N}$ fixation without affecting profits.

Keywords: clover root weevil, modelling, nitrogen fertiliser, pasture production, pasture quality, Sitona lepidus, Trifolium repens, white clover.
\end{abstract}

\section{INTRODUCTION}

In the absence of nitrogen $(\mathrm{N})$ fertiliser, agents that are detrimental to white clover's (Trifolium repens L.) abundance in New Zealand pastures have the potential to reduce pasture and animal productivity. Currently, clover root weevil (CRW) (Sitona lepidus Gyllenhal (Coleoptera: Curculionidae)) is demonstrating its potential to be such an agent in the North Island of New Zealand. The various life stages of CRW consume clover leaves, roots and nodules. Experimental and farm survey studies have found that CRW reduces white clover's abundance in pasture (Eerens et al. 1998; Eerens et al. 2005).

To date there have been limited studies that have attempted to quantify the economic impact of reduced clover content (Goldson et al. 2005). When estimating the cost of a reduction in clover, it is difficult to account for and integrate all the biological feed-back loops and interactions between clover, grazing animals, soil inorganic and organic pools and other pasture species. Even then these results would still need to be scaled up to a farm scale. Therefore, given the complexity and time-lags associated with this problem, it is considered that modelling is an appropriate first step to estimate the cost of CRW.

There were two parts to the modelling exercise presented in this paper. Firstly, a biophysical simulation model was used to determine the long-term impacts of CRW herbivory on pasture quantity and quality. Secondly, these pasture quantity and quality data were used in a decision support model to determine the impact on the animal productivity and financial returns of a 'typical' New Zealand sheep and beef farm. The production and financial implications of applying $\mathrm{N}$ fertiliser to replace the $\mathrm{N}$ lost through CRW damage to clover were also investigated. 


\section{MATERIALS AND METHODS}

A hypothetical sheep and beef farm in Waikato, New Zealand, was chosen for the case study farm for several reasons. Waikato was one of the first regions in which CRW was recorded (Barratt et al. 1996), so pest and plant populations have had the best chance of reaching a long-term state of equilibrium. In addition, small-plot experimental work on CRW impacts on pasture production has been conducted in Waikato (Gerard et al. 2006), and this was used to help parameterise the models. Finally, AgResearch's Ruakura site has the comprehensive climate data required for the biophysical simulation modelling.

\section{Biophysical simulation modelling}

The model EcoMod was used to simulate CRW weevil herbivory on clover plants and the flow-on implications for long-term pasture growth and quality. EcoMod is a mechanistic biophysical simulation model of a plant, soil and grazing animal pastoral ecosystem operating on a daily time-step (I.R. Johnson, unpubl. data). EcoMod contains modules that specify soil, plant and animal characteristics and also modules for specifying quantities and rules for system inputs, such as climate, grazing animal management, fertiliser and irrigation.

The model was parameterised to simulate an agro-ecosystem containing non-lactating dry sheep continuously grazing a perennial ryegrass (Lolium perenne L.) and white clover pasture using 33 years of climate data from AgResearch Ruakura. Three different EcoMod simulations were performed: (1) a base no CRW simulation (No CRW), (2) a CRW-infested simulation (+CRW) and (3) a CRW-infested simulation with $\mathrm{N}$ fertiliser added $(+\mathrm{CRW}+\mathrm{N})$ to compensate for the $\mathrm{N}$ lost due to $\mathrm{CRW}$ damage. This equated to approximately $20 \mathrm{~kg} \mathrm{~N} / \mathrm{ha} /$ year, applied as urea in four equal applications of $5 \mathrm{~kg} \mathrm{~N} / \mathrm{ha}$ in March, May, August and October.

The effect of CRW herbivory was simulated by incrementally altering the parameters in Table 1. Specifically, CRW adults consume clover leaves, which reduces clover's ability to capture light and assimilate carbon dioxide. This was simulated by reducing the maximum photosynthetic rate of clover relative to ryegrass. The herbivory of clover roots and nodules by CRW larvae was simulated by reducing the depth of clover's root distribution, increasing the rate of root senescence and increasing the respiratory cost of $\mathrm{N}$ fixation. A series of runs were conducted until clover/ryegrass composition within the model was comparable to that observed in a CRW small-plot trial (Gerard et al. 2006) and on-farm observations (Eerens et al. 1998).

TABLE 1: Key parameter differences between simulations with and without CRW.

\begin{tabular}{llcc}
\hline Parameter & & No CRW & +CRW \\
\hline Maximum photosynthetic rate & $\left(\mathrm{mgCO}_{2} /\left(\mathrm{m}^{2} \mathrm{~s}\right)\right)$ & 1 & 0.9 \\
Respiratory cost of N fixation & $(\mathrm{kgCl} / \mathrm{kgN})$ & 6 & 10 \\
Root senescence & $(\% / \mathrm{day})$ & 2 & 3 \\
Maximum root depth & $(\mathrm{cm})$ & 50 & 10 \\
Depth to 50\% of root distribution & $(\mathrm{cm})$ & 15 & 3 \\
\hline
\end{tabular}

\section{Decision support modelling}

The farm-scale consequences of CRW infestation were investigated using StockPol ${ }^{\circledR}$, a sheep/beef/deer farm decision support tool (Marshall et al. 1991). StockPol ${ }^{\circledR}$ enables the user to determine the biological feasibility and potential financial consequences of changes in physical resources (e.g. pasture growth rate) and farm management decisions (e.g. buying/selling dates for stock).

For the purpose of this exercise, a hypothetical 325 ha No CRW sheep and beef farm was created in StockPol ${ }^{\circledR}$ using mean monthly pasture growth and quality data generated in EcoMod assuming no CRW infestation. The No CRW farm had the following characteristics: 1500 cross-bred ewes with $150 \%$ weaning; 80 beef cows with $85 \%$ 
weaning; 75 Friesian bulls bought at 2 months and sold to the freezing works at 18-20 months; ewe lamb and heifer calf replacements reared on farm; all remaining lambs sold to the works; heifer calves not retained sold at auction at 6 months; beef steer calves retained until 2.5 years age and sold to the works; silage then hay made November to mid February from 60 ha; supplements fed out from May to September. Up-to-date (2006) costs and stock prices were used in calculating farm gross margins.

After establishing the No CRW farm scenario, pasture growth and quality inputs were altered according to that achieved under the +CRW simulation in EcoMod. The lower pasture growth and quality under CRW infestation resulted in metabolisable energy demand exceeding supply and, therefore, StockPol ${ }^{\circledR}$ declared the farm to be biologically infeasible. StockPol ${ }^{\circledR}$ then calculated the reduction in animal numbers required to return to a biologically feasible farm. The final farm scenario used the $+\mathrm{CRW}+\mathrm{N}$ growth and quality data from EcoMod.

\section{RESULTS}

The simulated CRW herbivory decreased mean clover abundance, pasture production, pasture quality and $\mathrm{N}$ fixation (Table 2). CRW herbivory also reduced clover root biomass. Applying $20 \mathrm{~kg} \mathrm{~N} / \mathrm{ha}$ to compensate for reduced $\mathrm{N}$ fixation under CRW infestation, increased pasture production and quality.

TABLE 2: Mean farm pasture growth, quality and composition without CRW and with CRW, either without or with nitrogen fertiliser.

\begin{tabular}{llccc}
\hline & & No CRW & +CRW & +CRW+N \\
\hline Annual pasture production & (kg dry matter (DM)/ha) & 9189 & 7932 & 9514 \\
Metabolisable energy & (MJ/kg DM) & 10.5 & 10.2 & 10.4 \\
Annual N fixation & (kg N/ha/year) & 60 & 42 & 41 \\
Shoot biomass & Ryegrass (t DM/ha) & 1.19 & 1.31 & 1.33 \\
Shoot biomass & Clover (t DM/ha) & 0.32 & 0.20 & 0.19 \\
Root biomass & Ryegrass (t DM/ha) & 0.50 & 0.54 & 0.57 \\
Root biomass & Clover (t DM/ha) & 0.18 & 0.09 & 0.09 \\
Pasture composition & Ryegrass (\%) & 79 & 87 & 88 \\
Pasture composition & Clover (\%) & 21 & 13 & 12 \\
\hline
\end{tabular}

The decrease in pasture production and quality under CRW infestation resulted in reduced carrying capacity of the hypothetical sheep and beef farm. StockPol ${ }^{\circledR}$ calculated that for the farm to return to biological feasibility, breeding ewe, breeding cow and bull beef numbers had to be reduced to 1260, 67 and 63 animals, respectively. Fewer breeding animals resulted in less stock for sale and, therefore, lower financial return per hectare of land (Table 3). Without CRW infestation, farm gross margin was $\$ 569 /$ ha compared to $\$ 478 /$ ha with CRW infestation. However, the increase in pasture production and quality when $\mathrm{N}$ was added, allowed animal stocking rates to return to near pre-infestation levels. Using the current average cost of $\mathrm{N}$ applied of $\$ 1.20 / \mathrm{kg} \mathrm{N}$, the increase in stocking rate resulted in a farm gross margin of $\$ 570 / \mathrm{ha}$.

\section{DISCUSSION}

The outcomes of this modelling exercise match the observations of farmers and researchers in Waikato (Eerens et al. 1998; Gerard et al. 2006). It has shown how simulated CRW herbivory reduced pasture production and quality, which had flow-on impacts on farm financial performance. However, given the current cost of $\mathrm{N}$ fertiliser, the reduction in $\mathrm{N}$ fixation can be compensated without financially penalising the farmer. In fact the current practice, on farms where CRW infestations occur and fertiliser application is not limited by topography and soil water availability, is to not only replace 
TABLE 3: Revenue, expenditure and gross margins (\$/ha) without CRW and with CRW, either without or with nitrogen fertiliser.

\begin{tabular}{llcrr}
\hline & & No CRW & +CRW & +CRW +N \\
\hline Sheep revenue & Sales-Purchases & 536 & 450 & 545 \\
& Wool & 102 & 92 & 103 \\
Beef revenue & Capital value change & 6 & 5 & 6 \\
& Sales-Purchases & 218 & 180 & 222 \\
Total Revenue & Capital value change & 4 & 3 & 4 \\
Crop \& feed costs & Hay and silage & $\mathbf{8 6 6}$ & $\mathbf{7 3 1}$ & $\mathbf{8 8 2}$ \\
& Nitrogen & 90 & 78 & 78 \\
Stock costs & Animal health & 0 & 0 & 24 \\
Interest on capital & Shearing & 51 & 43 & 52 \\
Total expenditure & & 38 & 34 & 38 \\
Gross margin & & 118 & 99 & 120 \\
& & $\mathbf{2 9 7}$ & $\mathbf{2 5 3}$ & $\mathbf{3 1 2}$ \\
\end{tabular}

the $\mathrm{N}$ deficit but to apply additional $\mathrm{N}$ to further increase pasture and animal growth and financial returns. This trend is only likely to change in the future if the cost of $\mathrm{N}$ fertiliser increases dramatically or if regional authorities place tighter restrictions on the amount of $\mathrm{N}$ fertiliser able to be applied.

This study has also demonstrated the utility of some of the biophysical and decision support modelling tools currently available. Biophysical models are integrated mathematical representations of real biological systems and their construction draws on decades of laboratory and field research knowledge. Integration of the biophysical model components allows for the expression of feed-back and flow-on effects that are a crucial part of biological systems. As illustrated in this exercise, changes to one system component (e.g. $\mathrm{N}$ fixation) impacts other system components (e.g. plant growth and animal numbers). Models also provide the ability to perform long-term experiments relatively quickly where system components can be easily altered and the consequences of which can be determined rapidly. This approach can identify areas for targeted experimentation in the laboratory or field, thereby providing a valuable first step in a research programme.

However, the limitations of these models need to be realised. There is a conflict between complexity and ease-of-use. Complex mechanistic models can often be adapted to many different situations but there may be tens to hundreds of parameter settings related to plants, soils and animals. This requires considerable knowledge and training to achieve appropriate and meaningful use of the model. Simpler empirical or decision support models are often easier to use but cannot be so readily adapted. This exercise has demonstrated that combining different modelling tools is a productive approach in gaining maximum value from modelling.

\section{REFERENCES}

Barratt BIP, Barker GM, Addison PJ 1996. Sitona lepidus Gyllenhal (Coleoptera: Curculionidae), a potential clover pest new to New Zealand. New Zealand Entomologist 19: 23-30.

Eerens JPJ, Hardwick S, Gerard PJ, Willoughby BE 2005. Clover root weevil (Sitona lepidus) in New Zealand: the story so far. Proceedings of the New Zealand Grassland Association 67: 19-22.

Eerens JPJ, Willoughby B, Kettlewell F, Hardwick S, Bay S 1998. The clover root weevil in northern pastures: on-farm observations of its impact on white clover. Proceedings of the New Zealand Grassland Association 60: 287-290. 
Gerard PJ, Hackell DL, Bell NL 2006. Impact of clover root weevil Sitona lepidus (Coleoptera: Curculionidae) larvae on herbage yield and species composition in a ryegrass-white clover sward. Bulletin of Entomological Research 96: In press.

Goldson SL, Rowarth JS, Caradus JR 2005. The impact of invasive invertebrate pests in pastoral agriculture: a review. New Zealand Journal of Agricultural Research 48: 401-415.

Marshall PR, McCall DG, Johns KL 1991. Stockpol: a decision support model for livestock farms. Proceedings of the New Zealand Grassland Association 53: $137-140$. 